\title{
Chemical Journal of Kazakhstan
}

ISSN 1813-1107

https://doi.org/10.51580/2021-1/2710-1185.11

Volume 1, Number 73 (2021), 103 - 118

УДК 541.132/.132.4:541.49

Т. К. ДЖУМАДИЛОВ ${ }^{1, *}$, Р. Г. КОНДАУРОВ ${ }^{1}$, А. М. ИМАНҒАЗЫ ${ }^{1}$, Х. ХИМЭРСЭН ${ }^{2}$

${ }^{1} \mathrm{AO}$ «Институт химических наук им. А.Б. Бектурова», Алматы, Республика Казахстан;

${ }^{2}$ Казахский национальный педагогический университет им. Абая,

Алматы, Республика Казахстан.

*E-mail: jumadilov@mail.ru

\section{ВЛИЯНИЕ СШИВАЮЩЕГО АГЕНТА НА ЭЛЕКТРОХИМИЧЕСКОЕ И КОНФОРМАЦИОННОЕ ПОВЕДЕНИЕ ПОЛИМЕРОВ С МОЛЕКУЛЯРНЫМИ ОТПЕЧАТКАМИ НА ОСНОВЕ МЕТАКРИЛОВОЙ КИСЛОТЫ И 4-ВИНИЛПИРИДИНА В ВОДНОЙ СРЕДЕ}

\begin{abstract}
Аннотация. Синтезированы полимеры с молекулярными отпечатками (ПМО) на основе метакриловой кислоты (МАК) и 4-винилпиридина(4ВП) двух видов (различие видов основано на применении этиленгликольдиметакрилата (ЭГДМА) и диэтиленгликольдиметакрилата (ДЭГДМА) в качестве сшивающего агента). В качестве шаблонов при синтезе применялись соли церия, празеодима, неодима, самария и европия. Также синтезированы контрольные образцы полимеров с молекулярными отпечатками (образцы, синтезированные точно таким же способом, но без шаблонов). Изучено электрохимическое и конформационное поведение синтезированных структур в водной среде. Полимеры с молекулярными отпечатками слабо подвергаются набуханию, ионизации вследствие плотной сшивки, при этом необходимо отметить, что высокая степень сшивки приводит к высокой механической прочности макромолекулярных структур. Сравнение измеряемых параметров (удельная электропроводность, $\mathrm{pH}$ ) полимеров с молекулярными отпечатками, содержащих шаблон, с контрольными образцами ПМО указывают на наличие полостей, комплементарных к шаблону (ион редкоземельного металла), примененному при их синтезе. В присутствии ПМО, синтезированных в присутствии ЭГДМА (ПМО-1), отмечаются более высокие значения удельной электропроводности и $\mathrm{pH}$ по сравнению с ПМО, синтезированных в присутствии ДЭГДМА (ПМО-2) вследствие менее плотной сшивки.
\end{abstract}

Ключевые слова: полимеры с молекулярными отпечатками, метакриловая кислота, 4-винилпиридин, шаблон, редкоземельные металлы.

Введение. Полимер с молекулярными отпечатками (ПМО) представляет собой полимер, который был обработан с использованием специальной техники молекулярного импринтинга, из-за чего появляются полости в полимерной матрице со сродством к выбранному "шаблону" молекулы [1]. Этот процесс обычно включает в себя инициирование полимеризации мономеров 
в присутствии молекулы-шаблона, которая извлекается впоследствии, таким образом оставляя взаимодополняющие полости. Такие полимеры обладают сродством к исходной молекуле и могут быть использованы в следующих областях: химическое разделение, катализ, молекулярные сенсоры и т.д.

Как известно, одним из основных требований, предъявляемых к сорбционным материалам, используемым для аналитических целей, является их высокая селективность. Как правило, данная задача решается путем формирования в полимере функциональных групп, обладающих селективностью подобно ионообменным смолам, либо, в случае иммуносорбентов, введением в состав полимера антител. Однако синтез таких полимеров является, как правило, дорогостоящим, а в ряде случаев невозможно подобрать соответствующие функциональные группы или антитела для эффективной сорбции заданного вещества. Одним из вариантов эффективных решений может быть создание высокоселективных сорбентов на основе полимерных систем, «структурно настраиваемых» на целевой сорбат на наноуровне. Типичным примером таких систем являются ПМО [2].

Молекулярный импринтинг, по сути, является искусственным крошечным «замком» для конкретной молекулы, которая служит в качестве миниатюрного «ключа» [3]. Подобно макромолекулярным рецепторам, полимер с молекулярными отпечатками захватывает конкретные химические вещества. Многочисленные биологические процессы от зондирования запахов до передачи сигналов между нервными и мышечными клетками основаны на подобной комбинации «замок-ключ». На протяжении многих десятилетий ученые пытались понять природу данных взаимодействий, часто напоминая при этом «взломщика», который пытается найти нужный ключ, соответствующий конкретным рецепторам. В настоящее время молекулярный импринтинг позволяет многим ученым самим создавать «замки» для определенных молекул. Они обрабатывают материал для создания конкретных полостей, которые по размеру, форме и функциональным группам, соответствуют целевой молекуле. Следует отметить, что одним из самых больших преимуществ искусственных рецепторов над естественными является свобода молекулярного дизайна. Их рамки никогда не ограничиваются белками, также различные скелеты (например, углеродные цепи и конденсированные ароматические кольца) могут быть использованы. Таким образом, устойчивость, гибкость и другие свойства могут быть свободно изменены в широких пределах в зависимости от необходимости. Даже функциональные группы, которые не встречаются в природе, могут быть использованы в этих техногенных соединениях. Кроме того, при необходимости, активность подобных структур в ответ к внешним воздействиям (фото-облучения, изменения $\mathrm{pH}$, электрическое или магнитное поле) может быть предоставлена с использованием соответствующих функциональных групп. Спектр функций искусственных полимеров с молекулярными отпечатками значительно шире, чем у естественных аналогов. 
Одним из основных требований, предъявляемых к сорбционным материалам, используемым для аналитических целей, является их высокая селективность. Как правило, данная задача решается путем формирования в полимере функциональных групп, обладающих избирательной сорбцией по отношению к определенным веществам, например, в случае иммуносорбентов, введением в состав полимера антител. Однако синтез таких полимеров является, как правило, дорогостоящим из-за сложностей, связанных с подбором соответствующих функциональных групп или антител для эффективной сорбции заданного вещества. Одним из вариантов эффективных решений может быть создание высокоселективных сорбентов на основе полимерных систем, «структурно настраиваемых» на целевой сорбат на наноуровне. К таким системам можно отнести полимеры с «молекулярными отпечатками», получаемые методом молекулярного импринтинга.

Молекулярный импринтинг является достаточно эффективной методикой для включения специфического распознавания шаблона анализируемого объекта в полимеры. Молекулярные характеристики распознавания этих полимеров напрямую зависят от комплементарного размера, формы объектов связывания, сообщаемого полимерам молекулами шаблона. В понятие комплементарности входит соответствие отпечатка шаблону как по размеру и форме, так и по наличию в отпечатке дополняющих функциональных групп, способных к взаимодействию с функциональными группами молекулы - шаблона. В основе селективности ПМО лежит молекулярное распознавание.

Молекулярное распознавание представляет собой избирательное связывание между двумя или более молекулами за счет нековалентных взаимодействий.

Молекулярное распознавание - одно из основных понятий супрамолекулярной химии. От обычного связывания между молекулами оно отличается селективностью. Молекулярное распознавание основано на наличии у одной молекулы (рецептора, или «хозяина») участка (области) избирательного связывания с другой молекулой (лигандом, или «гостем»). Для этого «хозяин» и «гость» должны проявлять комплементарность, то есть структурно и энергетически соответствовать друг другу.

Термин «молекулярное распознавание» обозначает специфичное взаимодействие между двумя или более молекулами путем образования нековалентных связей таких, как водородные связи, образования координационных связей с ионами металлов, гидрофобные силы, ван-дер-Ваальсовские взаимодействия, $\pi-\pi$ взаимодействия, галогеновые связи, электростатические и электромагнитные эффекты. В дополнение к этим прямым взаимодействиям также растворитель может играть доминирующую косвенную роль в управлении молекулярным распознаванием в растворе. «Хозяин» и «гость», участвующие в молекулярном распознавании, демонстрируют молекулярную комплементарность. 
Молекулярное распознавание предполагает накопление и хранение (на молекулярном уровне) и считывание (на супрамолекулярном уровне) информации. Именно поэтому оно играет важную роль в биологических системах.

Последние исследования показали, что элементы молекулярного распознавания могут быть синтетически произведены в наномасштабном режиме [4], обходя при этом потребность во встречающихся в природе элементах молекулярного распознавания для разработки чувствительных инструментов для малых молекул. Биомиметические полимеры, такие как пептоиды, могут быть использованы для распознавания более крупных биологических мишеней (белки) [5]. Конъюгация полимеров с синтетическими флуоресцентными наноматериалами может генерировать синтетические макромолекулярные структуры, служащие синтетическими антителами для распознавания и обнаружения оптических белков.

Химики продемонстрировали, что искусственные супрамолекулярные системы могут быть спроектированы и сконструированы с молекулярным распознаванием. Одним из самых ранних примеров такой системы являются краун-эфиры, которые способны избирательно связывать специфические катионы. Однако с тех пор было создано несколько искусственных систем [6-7].

Молекулярное распознавание можно подразделить на статическое молекулярное распознавание и динамическое молекулярное распознавание. Статическое молекулярное распознавание сравнивается с взаимодействием между ключом и замочной скважиной. Это реакция комплексообразования типа 1:1 между «молекулой-хозяином» и «молекулой-гостем» для образования комплекса «хозяин-гость». Для достижения расширенного статического молекулярного распознавания необходимо синтезировать области распознавания, которые являются специфичными для гостевых молекул.

В случае динамического молекулярного распознавания связывание первого «гостя» с первой областью связывания «хозяина» влияет на константу ассоциации второго «гостя» со второй областью связывания «хозяина» [8]. В случае положительных аллостерических систем связывание первого «гостя» увеличивает константу ассоциации второго «гостя». В то время как для отрицательных аллостерических систем связывание первого «гостя» уменьшает константу ассоциации второго «гостя». Динамический характер такого типа молекулярного распознавания особенно важен, поскольку он обеспечивает механизм регулирования связывания в биологических системах. Динамическое распознавание молекул может усилить способность различать несколько конкурирующих целей посредством механизма коррекционной корректуры. Динамическое распознавание молекул также изучается для применения в высокофункциональных химических датчиках и молекулярных устройствах.

На рисунке 1 представлено сравнение статическое молекулярного распознавания и динамического молекулярного распознавания. 


\section{Статическое:}

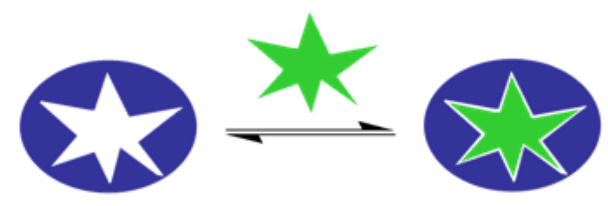

\section{Динамическое:}

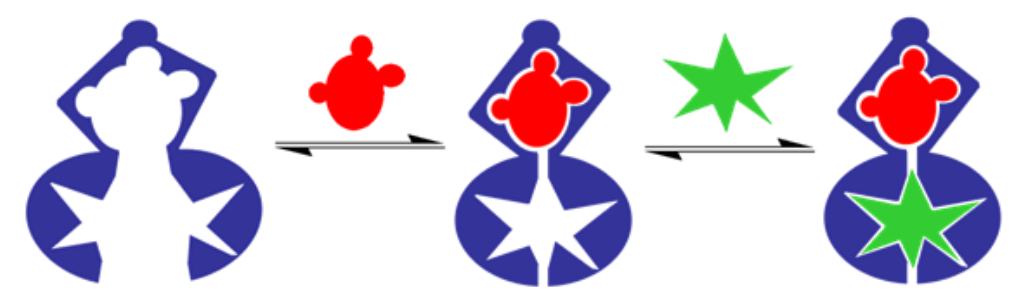

Рисунок 1 - Статическое и динамическое молекулярное распознавание

В недавних исследованиях, основанных на молекулярных представлениях и константах соблюдения, молекулярное распознавание определено как явление организации. Сложности, связанные с молекулярным распознаванием, заключаются в том, что даже для небольших молекул, таких как углеводы, процесс распознавания не может быть предсказан или разработан даже при условии, что сила каждой отдельной водородной связи точно известна [9]. Однако, как заключил Мобли с коллегами [10], точное предсказание событий молекулярного распознавания должно выходить за рамки статического моментального снимка одного кадра между «гостем» и «хозяином». Энтропии являются ключевыми факторами связывания термодинамики и должны учитываться для более точного прогнозирования процесса молекулярного распознавания. Энтропии не наблюдаются в одиночных связанных структурах (статический снимок).

Таким образом, способность полимеров с молекулярными отпечатками к распознаванию базируется на соответствии формы отпечатков и специфических функциональных группах внутри них молекулам-шаблонам. Специальные связывающие свойства ПМО следует отнести к особым взаимодействиям между шаблоном и функциональными группами в полимерной цепи, поэтому выбор мономеров является наиболее важной целью для получения высокоэффективных материалов с отпечатками.

Синтетические полимеры с молекулярными отпечатками (ПМО) получаются в результате молекулярного импринтинга - сополимеризации функционального и сшивающего мономеров в присутствии молекул-шаблонов. Можно ожидать, что синтезированный материал будет обладать высокой специфичностью по отношению к молекулам шаблона или близких к нему по строению соединений. Подобную специфичность в природе проявляют анти- 
тела, поэтому материалы, полученные методом молекулярного импринтинга, часто называют имитаторами антител («antibodymimics»).

На рисунке 2 представлен процесс получения полимера с молекулярными отпечатками. Как видно, вначале происходит образование предполимеризационного комплекса между функциональными мономерами и шаблоном, после чего следует процесс образования полимерной матрицы, содержащей в своей структуре молекулы шаблона и завершающим этапом является удаление молекулярного шаблона из полимерной матрицы и образование полостей, комплементарных шаблонной молекуле.

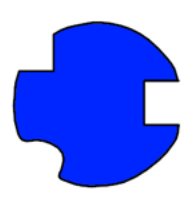

ІІаблон

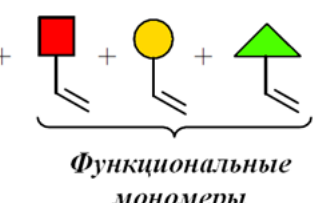

мономеры

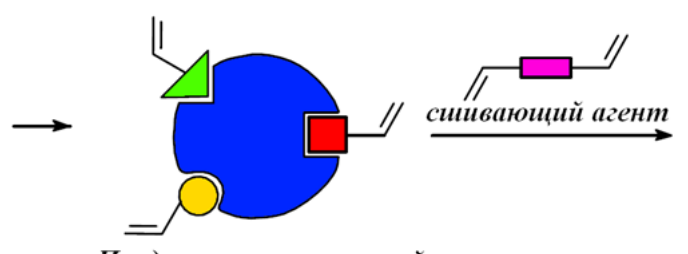

Предполимеризационный комплекс

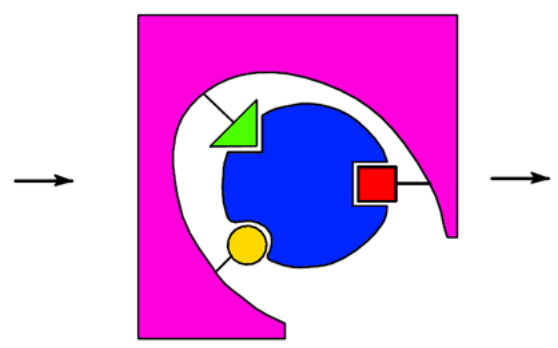

Полимер, содержаций иаблон

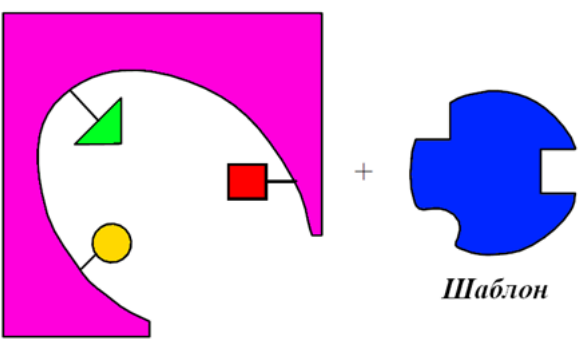

IIMO

Рисунок 2 - Синтез полимерных материалов с отпечатками

В настоящее время для синтеза полимеров с молекулярными отпечатками наиболее широко используется метод полимеризации в массе [11-13]. Стандартная методика получения ПМО этим способом включает несколько стадий:

1. Приготовление реакционной смеси. Шаблон добавляется к полимеризационной смеси, которая содержит функциональный мономер и сшивающий агент, а также инициатор полимеризации и необходимый для образования пор растворитель. В работАХ [14-18] анализировался выбор соотношения шаблон : функциональный мономер : сшивающий мономер, обеспечивающего необходимые свойства ПМО. Как правило, функциональный мономер берется в четырех- и более кратном избытке по отношению к шаблону $[16,17]$, количество сшивающего компонента в реакционной среде максимально и достигает 70-90\% [18]. Стандартное объемное соотношение мономер : порогенный растворитель составляет 3:4. Хотя полярные растворители (хлороформ, дихлорметан) и характеризуются большой способностью к 
порообразованию, для нековалентного импринтинга предпочтительны такие менее полярные растворители, как бензол, толуол или ацетонитрил, обеспечивающие прочность нековалентных связей [17]. Растворители, диссоциирующие с отщеплением протонов, затрудняют полимеризацию и дестабилизируют водородные связи. Поэтому применение, например, воды или метанола в качестве растворителей при получении ПМО нежелательно.

2. Реакция полимеризации. Полимеризация может инициироваться либо нагреванием реакционной смеси до 50-60 $\mathrm{C}$, либо ультрафиолетовым облучением. Второй вариант предпочтительнее для нековалентного импринтинга, поскольку сила водородных и ионных взаимодействий мономера с молекулами шаблона с ростом температуры снижается [11]. ПМО обычно синтезируют методом свободнорадикальной полимеризации, широко применяемым для крупнотоннажного производства пластмасс. Этот выбор обусловлен возможностью конверсии различных виниловых мономеров (этилена, стирола, метилметакрилата и многих других), относительно мягкими условиями реакции, отсутствием специальных требований к чистоте реагентов, а также дешевизной коммерчески доступных мономеров, содержащих различные функциональные группы.

Механизм радикальной полимеризации подробно описан в работе [19]. Реакция состоит из трех стадий - инициации, роста полимерных цепей и терминации. Стадия роста цепей обычно гораздо быстрее, чем инициация; от начала роста новой полимерной цепочки до образования высокомолекулярного полимера и последующей терминации проходит всего несколько секунд. Это означает, что высокомолекулярный продукт присутствует в реакционной смеси даже тогда, когда израсходованное количество мономера минимально. Источниками свободных радикалов для полимеризации могут служить разнообразные инициаторы.

3. Получение полимерных частиц. Поскольку ПМО чаще всего используются в виде порошка частиц микронного размера, образовавшийся жесткий пористый полимерный монолит механически размалывают с получением неоднородных частиц. Гомогенизация по размеру осуществляется путем многократного просеивания через сита с определенным диаметром пор и последующей седиментации. Потери полимерного материала в ходе этих процедур могут составлять 50\% и выше [20].

4. Отмывка полимера. Заключительный этап получения ПМО - освобождение молекулярных отпечатков от шаблона. Способ удаления шаблона зависит от природы его связи с мономером. При ковалентном импринтинге проводится химическое разрушение связей, при нековалентном - многократная экстракция смесью органических растворителей (как правило, последовательно метанол: уксусная кислота, метанол). Высушенные под вакуумом частицы хранятся длительное время без ущерба для физико-химических и прикладных свойств.

Большинство разработок в производстве ПМО в течение последнего десятилетия предстают в форме новых методов полимеризации в попытке 
контролировать расположение мономеров и, следовательно, структуру полимеров. Однако среди проводимых исследований очень мало успехов в эффективном удалении шаблона из ПМО после полимеризации. Из-за этого пренебрежения процесс удаления шаблонов в настоящее время является наименее экономичным и наиболее трудоемким процессом в производстве ПМО. Кроме того, для возможности полноценного использования возможностей ПМО в аналитических и биотехнологических приложениях, необходим эффективный процесс удаления шаблона. Основные трудности удаления шаблона представлены на рисунке 3.

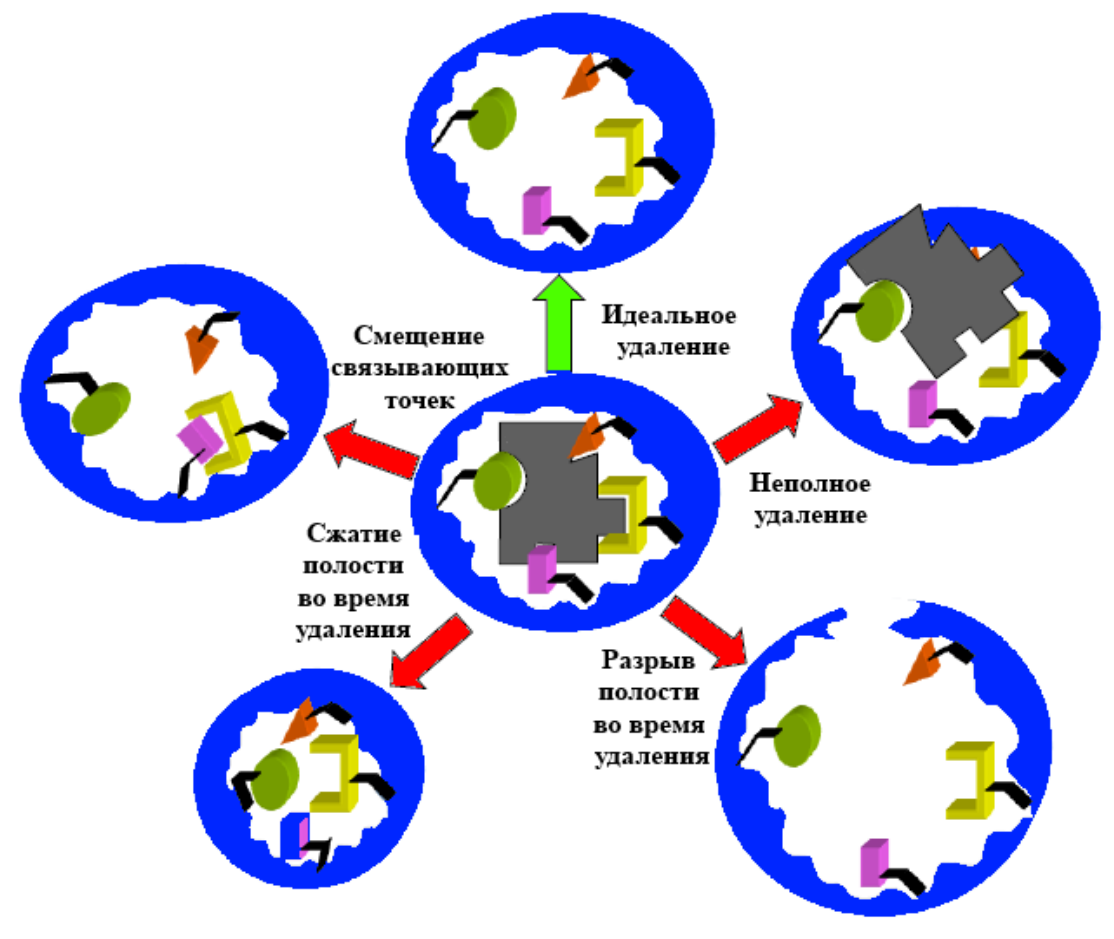

Рисунок 3 - Возможные трудности при удалении шаблона

\section{ЭКСПЕРИМЕНТАЛЬНАЯ ЧАСТЬ}

Оборудование. Для измерения удельной электропроводности был использован кондуктометр Эксперт-002 (РФ), pH растворов определяли на pH-метре Metrohm 827 pH-Lab (Швейцария). Массу набухших образцов гидрогелей для последующего расчета степени набухания $(\alpha)$ определяли взвешиванием на электронных аналитических весах SHIMADZUAY220 (Япония).

Maтериаль. Полимеры с молекулярными отпечатками были синтезированы методом суспензионной полимеризации. В качестве шаблонов были 
выбраны нитраты церия, празеодима, неодима, самария, европия (в рамках выполнения НИР не предполагается проведение опытов с прометием поскольку в природе данный металл встречается в виде радиоактивных изотопов). В качестве функциональных мономеров были выбраны метакриловая кислота (МАК) и 4-винилпиридин (4ВП), сшивающий агент этиленгликоль диметакрилат (ЭГДМА) и диэтиленгликольдиметакрилат (ДЭГДМА), в качестве инициатора был применен азобисизобутиронитрил (АИБН), в качестве стабилизатора была использована гидроксиэтилцеллюлоза (ГЭЦ), толуол был выбран в качестве порообразователя. В качестве среды для полимеризации была применена деионизованная вода. Состав реакционной смеси выглядит следующим образом: ион металла $\left(\mathrm{Ce}^{3+} / \mathrm{Pr}^{3+} / \mathrm{Nd}^{3+} / \mathrm{Sm}^{3+} / \mathrm{Eu}^{3+}\right): \mathrm{AАК:4ВП:ЭГДМА/ДЭГДМА=1:2:2:8.} \mathrm{Реакция} \mathrm{по-}$ лимеризации проводилась в 500 мл трехгорлой круглодонной колбе (реактор) с механической мешалкой. Компоненты добавлялись в реактор в следующей последовательности: МАК, 4ВП, соль металла, ЭГДМА, 13 мл толуола, ГЭЦ в количестве $3,5 \%$ от количества мономерной системы (МАК+4ВП). Скорость перемешивания - 230 оборотов в минуту. Реакция проводилась в течении 20 минут при комнатной температуре, затем на протяжении 6,5 часов при $75^{\circ} \mathrm{C}$ в токе азота. После полимеризации получившиеся частицы ПМО-1 и ПМО-2 (при синтезе ПМО-1 применялся ЭГДМА, при синтезе ПМО-2 применялся ДЭГДМА) были тщательно промыты деионизованной водой и ацетоном для удаления примесей и остатков непрореагировавших мономеров. Получившиеся гранулы были подвергнуты вакуумной сушке на протяжении 24 часов. Для удаления шаблона была использована $1 \mathrm{M}$ азотная кислота при перемешивании на протяжении 1 часа. Для полного удаления металлов цикл промыки был повторен 30 раз, после чего ПМО были промыты деионизованной водой и подвергнуты сушке в вакууме на протяжении 24 часов. Для контроля селективности ПМО-1 и ПМО-2 были синтезированы контрольные образцы кПМО-1 и кПМО-2, отличающиеся только тем, что при их синтезе не добавляется шаблон.

Эксперимент. Эксперименты проведены при комнатной температуре. Изучение исходных электрохимических свойств индивидуальных полимерных гидрогелей ПАК, ПМАК, П4ВП, П2М5ВП; интергелевых систем на их основе; полимеров с молекулярными отпечатками проводилось следующим образом:

1. Расчетное количество каждой макромолекулярной структуры (редкосшитые полимерные гидрогели; полимеры с молекулярными отпечатками) в сухом виде помещалось в стеклянный стакан. В случае интергелевых систем расчетное количество каждого гидрогеля в сухом виде помещалось в специальный стеклянный фильтр, поры которого проницаемы для низкомолекулярных ионов, но непроницаемы для дисперсии гидрогелей (поликислоты помещались в один фильтр; полиоснования - в другой - так и достигалось дистанционное взаимодействие). 
2. На протяжении 2 сут проводилось измерение электрохимических свойств (удельная электропроводность, $\mathrm{pH}$ ) водных растворов и массы образцов полимерных образцов гидрогелей. Измерение электропроводности и рН было проведено в отсутствиЕ гидрогелей в водной среде. Степень набухания была рассчитана по формуле:

$$
\alpha=\frac{m_{2}-m_{1}}{m_{1}}
$$

где $\mathrm{m}_{1}-$ вес сухого гидрогеля; $\mathrm{m}_{2}$ - вес набухшего гидрогеля.

\section{РЕЗУЛЬТАТЫ И ОБСУЖДЕНИЯ}

В таблицах 1, 2 представлены значения удельной электропроводности воды в присутствии макромолекулярных структур ПМО-1 и ПМО-2. Со временем электропроводность возрастает со временем. Слабая ионизация макромолекул является результатом плотной сшивки в струкутрах ПМО-1 и ПМО-2. Необходимо отметить, что более плотная сшивка получается в случае использования ДЭГДМА в качестве сшивающего агента - об этом свидетельствует тот факт, что электропроводность воды в присутствии структуры кПМО-2 ниже более чем на 25\% по сравнению с кПМО-1. Подобная тенденция с более низкой степнью ионизации наблюдается и в случае со структурами ПМО-2(Ce), ПМО-2(Pr), ПМО-2(Nd), ПМО-2(Sm), ПMO-2(Eu) при сравнении значений электропроводности с присутствием структур ПМО1(Ce), ПМО-1(Pr), ПМО-1(Nd), ПМО-1(Sm), ПМО-1(Eu) в водной среде. Рост удельной электропроводности воды со временем связан как с ионизацией структур ПМО-1 и ПМО-2, так и с диссоциацией воды на ионы водорода и гидроксил ионы.

Таблица 1 - Удельная электропроводность воды в присутствии структур ПМО-1

\begin{tabular}{|c|c|c|c|c|c|c|}
\hline \multirow{2}{*}{$\begin{array}{c}\tau, \\
\text { ч }\end{array}$} & \multicolumn{6}{|c|}{$\chi$, мкСм/см } \\
\cline { 2 - 7 } & кПМО-1 & ПМО-1(Сe) & ПМО-1(Pr) & ПМО-1(Nd) & ПМО-1(Sm) & ПМО-1(Eu) \\
\hline 0 & 0,50 & 0,50 & 0,50 & 0,50 & 0,50 & 0,50 \\
\hline 0,5 & 1,55 & 0,70 & 0,56 & 0,20 & 0,16 & 0,07 \\
\hline 1 & 1,51 & 0,69 & 0,55 & 0,20 & 0,15 & 0,07 \\
\hline 2 & 1,74 & 0,79 & 0,63 & 0,23 & 0,18 & 0,08 \\
\hline 6 & 3,49 & 1,59 & 1,27 & 0,46 & 0,36 & 0,17 \\
\hline 24 & 4,08 & 1,85 & 1,48 & 0,53 & 0,41 & 0,19 \\
\hline 48 & 4,30 & 1,95 & 1,56 & 0,56 & 0,44 & 0,20 \\
\hline
\end{tabular}


Таблица 2 - Удельная электропроводность воды в присутствии структур ПМО-2

\begin{tabular}{|c|c|c|c|c|c|c|}
\hline \multirow{2}{*}{$\begin{array}{c}\tau, \\
\text { ч }\end{array}$} & \multicolumn{6}{|c|}{$\chi$, мкСм/см } \\
\cline { 2 - 7 } & кПМО-2 & ПМО-2(Се) & ПМО-2(Pr) & ПМО-2(Nd) & ПМО-2(Sm) & ПМО-2(Еu) \\
\hline 0 & 0,50 & 0,50 & 0,50 & 0,50 & 0,50 & 0,50 \\
\hline 0,5 & 1,12 & 0,56 & 0,45 & 0,16 & 0,13 & 0,06 \\
\hline 1 & 1,10 & 0,55 & 0,44 & 0,16 & 0,12 & 0,06 \\
\hline 2 & 1,26 & 0,63 & 0,51 & 0,18 & 0,14 & 0,07 \\
\hline 6 & 2,54 & 1,27 & 1,02 & 0,37 & 0,28 & 0,13 \\
\hline 24 & 2,96 & 1,48 & 1,19 & 0,43 & 0,33 & 0,15 \\
\hline 48 & 3,12 & 1,56 & 1,25 & 0,45 & 0,35 & 0,16 \\
\hline
\end{tabular}

В таблицах 3, 4 представлены значения $\mathrm{pH}$ воды в присутствии макромолекулярных структур ПМО-1 и ПМО-2. Получены данные по концентрации ионов водорода в водной среде подтверждают гипотезу о том, что в случае структур ПМО-1 (как и контрольного образца, так и полимеров с шаблоном металла) степень ионизации выше чем в случае со структурой ПМО-2 вследствие меньшей плотности сшивки. Значения рН воды в присутствии кПМО-1 выше на 15\% по сравнению с кПМО-2, это явление указывает на то, что происходит более интенсивная ионизация структуры с молекулярными отпечатками, при синтезе которой использовался ЭГДМА в качестве сшивающего агента. Говоря иначе, происходит ионизация структуры за счет ассоциации протонов, образовавшихся при диссоциации молекул воды. Этим присоединением и обусловлено снижение значений $\mathrm{pH}$ водной среды.

Таблица 3 - рН воды в присутствии структур ПМО-1

\begin{tabular}{|c|c|c|c|c|c|c|}
\hline \multirow{2}{*}{$\begin{array}{c}\tau \\
\text { ч }\end{array}$} & \multicolumn{6}{|c|}{$\mathrm{pH}$} \\
\cline { 2 - 7 } & кПМО-1 & ПМО-1(Ce) & ПМО-1(Pr) & ПМО-1(Nd) & ПМО-1(Sm) & ПМО-1(Eu) \\
\hline 0 & 5,55 & 5,55 & 5,55 & 5,55 & 5,55 & 5,55 \\
\hline 0,5 & 5,49 & 4,95 & 4,97 & 4,98 & 5,00 & 5,03 \\
\hline 1 & 5,39 & 4,87 & 4,88 & 4,90 & 4,92 & 4,95 \\
\hline 2 & 5,30 & 4,79 & 4,80 & 4,82 & 4,83 & 4,86 \\
\hline 6 & 5,22 & 4,71 & 4,73 & 4,74 & 4,76 & 4,79 \\
\hline 24 & 5,14 & 4,64 & 4,65 & 4,67 & 4,68 & 4,72 \\
\hline 48 & 5,09 & 4,60 & 4,61 & 4,63 & 4,64 & 4,67 \\
\hline
\end{tabular}


Таблица 4 - рН воды в присутствии структур ПМО-2

\begin{tabular}{|c|c|c|c|c|c|c|}
\hline \multirow{2}{*}{$\begin{array}{c}\boldsymbol{7} \\
\text { ч }\end{array}$} & \multicolumn{6}{|c|}{$\mathrm{pH}$} \\
\cline { 2 - 7 } & кПМО-2 & ПМО-2(Ce) & ПMO-2(Pr) & ПMO-2(Nd) & ПMO-2(Sm) & ПMO-2(Eu) \\
\hline 0 & 5,55 & 5,55 & 5,55 & 5,55 & 5,55 & 5,55 \\
\hline 0,5 & 5,36 & 5,40 & 5,41 & 5,43 & 5,45 & 5,49 \\
\hline 1 & 5,11 & 5,15 & 5,16 & 5,18 & 5,20 & 5,23 \\
\hline 2 & 4,91 & 4,95 & 4,97 & 4,98 & 5,00 & 5,03 \\
\hline 6 & 4,54 & 4,58 & 4,59 & 4,61 & 4,62 & 4,65 \\
\hline 24 & 4,52 & 4,56 & 4,57 & 4,59 & 4,60 & 4,63 \\
\hline 48 & 4,33 & 4,36 & 4,37 & 4,39 & 4,40 & 4,43 \\
\hline
\end{tabular}

В таблицах 5, 6 представлены значения степени набухания структур кПМО-1 и кПМО-2, а также их производных (ПМО-1(Се), ПМО-1(Pr), ПМО1(Nd), ПMO-1(Sm), ПMO-1(Eu), ПMO-2(Ce), ПMO-2(Pr), ПMO-2(Nd), ПMO2(Sm), ПМО-2(Eu)). Со временем происходит поглощение достаточно малых количеств воды, о чем свидетельствуют низкие значения степени набухания.

Таблица 5 - Степень набухания структур ПМО-1 в водной среде

\begin{tabular}{|c|c|c|c|c|c|c|}
\hline \multirow{2}{*}{$\begin{array}{c}\tau, \\
\text { ч }\end{array}$} & \multicolumn{6}{|c|}{$\alpha, \Gamma / \Gamma$} \\
\cline { 2 - 7 } & кПМО-1 & ПМО-1(Ce) & ПМО-1(Pr) & ПМО-1(Nd) & ПMO-1(Sm) & ПМО-1(Еu) \\
\hline 0 & 0 & 0 & 0 & 0 & 0 & 0 \\
\hline 0,5 & 0,23 & 0,07 & 0,06 & 0,06 & 0,05 & 0,05 \\
\hline 1 & 0,36 & 0,11 & 0,10 & 0,09 & 0,08 & 0,08 \\
\hline 2 & 0,44 & 0,13 & 0,12 & 0,11 & 0,10 & 0,09 \\
\hline 6 & 0,49 & 0,15 & 0,13 & 0,12 & 0,11 & 0,10 \\
\hline 24 & 0,65 & 0,20 & 0,18 & 0,16 & 0,15 & 0,14 \\
\hline 48 & 0,71 & 0,21 & 0,19 & 0,17 & 0,16 & 0,15 \\
\hline
\end{tabular}

Таблица 6 - Степень набухания структур ПМО-2 в водной среде

\begin{tabular}{|c|c|c|c|c|c|c|}
\hline \multirow{2}{*}{$\begin{array}{c}\tau, \\
\text { ч }\end{array}$} & \multicolumn{7}{|c|}{$\alpha, \Gamma / \Gamma$} \\
\cline { 2 - 7 } & кПМО-2 & ПМО-2(C) & ПМО-2(Pr) & ПМО-2(Nd) & ПМО-2(Sm) & ПMO-2(Eu) \\
\hline 0 & 0 & 0 & 0 & 0 & 0 & 0 \\
\hline 0,5 & 0,18 & 0,06 & 0,05 & 0,04 & 0,04 & 0,04 \\
\hline 1 & 0,29 & 0,09 & 0,08 & 0,07 & 0,07 & 0,06 \\
\hline 2 & 0,35 & 0,11 & 0,10 & 0,08 & 0,08 & 0,07 \\
\hline 6 & 0,39 & 0,12 & 0,11 & 0,09 & 0,09 & 0,08 \\
\hline 24 & 0,52 & 0,16 & 0,14 & 0,12 & 0,12 & 0,11 \\
\hline 48 & 0,57 & 0,17 & 0,15 & 0,14 & 0,13 & 0,12 \\
\hline
\end{tabular}


Высокая плотность сшивки приводит к существенному улучшению физикомеханических свойств, однако практически полностью теряется возможность изменять конформацию макромолекул в процессе их ионизации. Как отмечалось выше, структура ПМО-2 и ее производные имеют более плотную сшивку, вследствие чего значения степени набухания в этом случае ниже по сравнению со структурой ПМО-1 и ее производными.

Полученные результаты изучения свойств синтезированных ПМО (таблицы 5,6 ) указывают на то, что синтезированные структуры ПМО-1 и ПМО-2 действительно имеют полости, комплементарные к шаблону (ион редкоземельного металла), примененному при их синтезе. Об этом свидетельствуют более низкие значения удельной электропроводности, $\mathrm{pH}$ и степени набухания структур ПМО с шаблоном при сравнении с контрольным образцом.

Заключение. Полимеры с молекулярными отпечатками обладают высокой механической прочностью благодаря высокой степени сшивки, при этом они слабо подвергаются набуханию, ионизации. Более низкие значения удельной электропроводности, $\mathrm{pH}$ и степени набухания структур ПМО с шаблоном при сравнении с контрольным образцом свидетельствуют о наличии полостей, комплементарных к шаблону (ион редкоземельного металла), примененному при их синтезе.

Данная работа выполнена в рамках финансирования грантовых исследований КН МОН РК (проект АР08856668).

\section{ЛИТЕРАТУРА}

[1] Гендриксон О.Д., Жердев А.В., Дзантиев Б.Б. Молекулярноимпринтированные полимеры и их применение в биохимическом анализе // Успехи биологической химии. - 2006. T. 46. - С. 149-192.

[2] Дмитриенко С.Г., Апяри В.В. Полимеры с молекулярными отпечатками: синтез, свойства, применение в анализе реальных объектов. - М.: Наука, 2015. - С. 332-374.

[3] Zahedi P., Ziaee M., Abdouss M., Farazin A., Mizaikoff B. Biomacromolecule templatebased molecularly imprinted polymers with an emphasis on their synthesis strategies: a review // Polymers for advanced technologies. - 2016. - Vol. 9. - P. 413-427.

[4] Zhang J., Landry M.P., Barone P.W., Kim J.-H., Lin S., Ulissi Z.W., Lin D., Mu B., Boghossian A.A., Hilmer A.J., Rwei A., Hinckley A.C., Kruss S., Shandell M.A., Nair N., Blake S., Şen F., Şen S., Croy R.G., Li D., Yum K., Ahn J.-H., Jin H., Heller D.A., Essigmann J.M., Blankschtein D., Strano M.S. Molecular recognition using corona phase complexes made of synthetic polymers adsorbed on carbon nanotubes // Nature nanotechnology. - 2013. - Vol. 8. - P. 959-968.

[5] Mannige R.V., Haxton T.K., Proulx C., Robertson E.J., Battigelli A., Butterfoss G.L., Zuckermann R.N., Whitelam S. Peptoidnanosheets exhibit a new secondary-structure motif // Nature. - 2015. - Vol. 526. - P. 415-420.

[6] Baron R., McCammon J.A. Molecular recognition and ligand binding // Annual review of physical chemistry. - 2013. - Vol. 64. - P. 151-175.

[7] Lehn J.-M. Supramolecular Chemistry. - Weinheim: Wiley-VCH, 1995. - 281 p.

[8] Shinkai S., Ikeda M., Sugasaki A., Takeuchi M. Positive allosteric systems designed on dynamic supramolecular scaffolds: toward switching and amplification of guest affinity and selectivity // Accounts of chemical research. - 2001. - Vol. 34. - P. 494-503.

[9] Grunenberg J. Complexity in molecular recognition // Physical chemistry chemical physics. - 2011. - Vol. 13. - P. 10136-10146.

[10] Mobley D.L., Dill K.A. Binding of small-molecule ligands to proteins: "what you see" is not always "what you get" // Structure. - 2009. - Vol. 17. - P. 489-498. 
[11] Wulff, G. Molecular imprinting in cross-linked materials with the aid of molecular templates - a way towards artificial antibodies // Angewandte chemie international edition in English. 1995. - Vol. 34. - P. 1812-1832.

[12] Mosbach K., Ramström O. The emerging technique of molecular imprinting and its future impact on biotechnology // Nature biotechnology. - 1996. - Vol. 14. - P. 163-170.

[13] Ansell R.J., Ramström O., Mosbach K. Towards artificial antibodies prepared by molecular imprinting // Clinical chemistry. - 1996. - Vol. 42. - P. 1506-1512.

[14] Andersson H.S., Karlsson J.G., Piletsky S.A., Koch-Schmidt A.-C., Mosbach K., Nicholls Y. Study of the nature of recognition in molecularly imprinted polymers, II: Influence of monomertemplate ratio and sample load on retention and selectivity // Journal of chromatography A. - 1999. Vol. 848. - P. 39-49.

[15] Baggiani C., Anfossi L., Giovannoli C., Tozzi C Binding properties of 2, 4, 5-trichlorophenoxyacetic acid-imprinted polymers prepared with different molar ratios between template and functional monomer // Talanta. - 2004. - Vol. 62. - P. 1029-1034.

[16] Yilmaz E., Mosback K., Haupt K. Influence of functional and cross-linking monomers and the amount of template on the performance of molecularly imprinted polymers in binding assays // Analytical communications. - 1999. - Vol. 36. - P. 167-170.

[17] Cormack P.A., Elorza A.Z. Molecularly imprinted polymers: synthesis and characterisation // Journal of chromatography B. - 2004. - Vol. 804. - P. 173-182.

[18] Masque N., Marce R.M., Borrul F. Molecularly imprinted polymers: new tailor-made materials for selective solid-phase extraction // Trends in analytical chemistry. - 2001. - Vol. 20. - P. 477-486.

[19] Billmeyer F.W. Textbook of Polymer Science. - New York: Wiley, 1984. - 608 p.

[20] Nicholls I.A., Ramström O., Mosbach K. Insights into the role of the hydrogen bond and hydrophobic effect on recognition in molecularly imprinted polymer synthetic peptide receptor mimics// Journal of chromatography A. - 1995. - Vol. 691. - P. 349-353.

\section{REFERENCES}

[1] Gendrikson O.D., Zherdev A.V., Dzantiev B.B. Molekulyarnoimprintirovannye polimery i ih primenenie v biohimicheskom analize // Uspekhi biologicheskoi himii. 2006. Vol. 46. P. 149-192.

[2] Dmitrienko S.G., Apyari V.V. Polimery s molekulyarnymi otpechatkami: sintez, svojstva, primenenie v analize real'nyh ob"ektov. M.: Nauka, 2015. P. 332-374.

[3] Zahedi P., Ziaee M., Abdouss M., Farazin A., Mizaikoff B. Biomacromolecule templatebased molecularly imprinted polymers with an emphasis on their synthesis strategies: a review // Polymers for advanced technologies. 2016. Vol. 9. P. 413-427.

[4] Zhang J., Landry M.P., Barone P.W., Kim J.-H., Lin S., Ulissi Z.W., Lin D., Mu B., Boghossian A.A., Hilmer A.J., Rwei A., Hinckley A.C., Kruss S., Shandell M.A., Nair N., Blake S., Şen F., Şen S., Croy R.G., Li D., Yum K., Ahn J.-H., Jin H., Heller D.A., Essigmann J.M., Blankschtein D., Strano M.S. Molecular recognition using corona phase complexes made of synthetic polymers adsorbed on carbon nanotubes // Nature nanotechnology. 2013. Vol. 8. P. 959-968.

[5] Mannige R.V., Haxton T.K., Proulx C., Robertson E.J., Battigelli A., Butterfoss G.L., Zuckermann R.N., Whitelam S. Peptoidnanosheets exhibit a new secondary-structure motif // Nature. 2015. Vol. 526. P. 415-420.

[6] Baron R., McCammon J.A. Molecular recognition and ligand binding // Annual review of physical chemistry. 2013. Vol. 64. P. 151-175.

[7] Lehn J.-M. Supramolecular Chemistry. Weinheim: Wiley-VCH, 1995. 281 p.

[8] Shinkai S., Ikeda M., Sugasaki A., Takeuchi M. Positive allosteric systems designed on dynamic supramolecular scaffolds: toward switching and amplification of guest affinity and selectivity // Accounts of chemical research. 2001. Vol. 34. P. 494-503.

[9] Grunenberg J. Complexity in molecular recognition // Physical chemistry chemical physics. 2011. Vol. 13. P. 10136-10146.

[10] Mobley D.L., Dill K.A. Binding of small-molecule ligands to proteins: "what you see" is not always "what you get" // Structure. 2009. Vol. 17. P. 489-498.

[11] Wulff, G. Molecular imprinting in cross-linked materials with the aid of molecular templates - a way towards artificial antibodies // Angewandte chemie international edition in English. 1995. Vol. 34. P. 1812-1832. 
[12] Mosbach K., Ramström O. The emerging technique of molecular imprinting and its future impact on biotechnology // Nature biotechnology. 1996. Vol. 14. P. 163-170.

[13] Ansell R.J., Ramström O., Mosbach K. Towards artificial antibodies prepared by molecular imprinting // Clinical chemistry. 1996. Vol. 42. P. 1506-1512.

[14] Andersson H.S., Karlsson J.G., Piletsky S.A., Koch-Schmidt A.-C., Mosbach K., Nicholls Y. Study of the nature of recognition in molecularly imprinted polymers, II: Influence of monomertemplate ratio and sample load on retention and selectivity // Journal of chromatography A. 1999. Vol. 848. P. 39-49.

[15] Baggiani C., Anfossi L., Giovannoli C., Tozzi C Binding properties of 2, 4, 5-trichlorophenoxyacetic acid-imprinted polymers prepared with different molar ratios between template and functional monomer // Talanta. 2004. Vol. 62. P. 1029-1034.

[16] Yilmaz E., Mosback K., Haupt K. Influence of functional and cross-linking monomers and the amount of template on the performance of molecularly imprinted polymers in binding assays // Analytical communications. 1999. Vol. 36. P. 167-170.

[17] Cormack P.A., Elorza A.Z. Molecularly imprinted polymers: synthesis and characterrisation // Journal of chromatography B. 2004. Vol. 804. P. 173-182.

[18] Masque N., Marce R.M., Borrul F. Molecularly imprinted polymers: new tailor-made materials for selective solid-phase extraction // Trends in analytical chemistry. 2001. Vol. 20. P. 477-486.

[19] Billmeyer F.W. Textbook of Polymer Science. New York: Wiley, 1984. 608 p.

[20] Nicholls I.A., Ramström O., Mosbach K. Insights into the role of the hydrogen bond and hydrophobic effect on recognition in molecularly imprinted polymer synthetic peptide receptor mimics// Journal of chromatography A. 1995. Vol. 691. P. 349-353.

\title{
Резюме
}

\author{
Т. К. Джумадилов, Р. Г. Кондауров, А. М. Иманвазы, Х. Химэрсэн
}

\section{СУ ОРТАСЫНДА МЕТАКРИЛ ҚЫШҚЫЛЫ МЕН 4-ВИНИЛПИРИДИНГЕ НЕГІЗДЕЛГЕН МОЛЕКУЛАЛЫҚ ТАНБАЛЫ ПОЛИМЕРЛЕРДІН ЭЛЕКТРОХИМИЯЛЫҚ ЖӘНЕ КОНФОРМАЦИЯЛЫҚ ҚАСИЕТТЕРІНЕ ТІГУШІ АГЕНТТІН ӘСЕРІ}

Метакрил қышқылы (МАҚ) және 4-винилпиридин (4ВП) негізінде молекулалық таңбалы полимерлердің екі түрі (байланыстырушы агент ретінде бірінде этиленгликольдиметакрилат (ЭГДМА), екіншісінде диэтиленгликольдиметакрилат (ДЭГДМА) қолданылды) синтезделді. Синтез барысында шаблон ретінде церий, празеодим, неодим, самарий жәнеевропий тұздары қолданылды. Сондай-ақ молекулалық таңбалы полимерлердің бақылаушы үлгілері (дәл сондай әдіспен синтезделген үлгілер, бірақ шаблонсыз) синтезделді. Синтезделген құрылымдардың су ортасындағы электрохимиялық және конформациялық қасиеттері зерттелді. Молекулалық таңбалы полимерлер тығыз тігілгендіктен ісінуге, ионизацияға нашар ұшырайды, ал тігудің жоғары дәрежесі макромолекулалық құрылымдардың жоғары механикалық беріктігіне әкеледі.

Шаблоны бар молекулалық таңбалы полимерлердің параметрлерін (меншікті электр өткізгіштігі, рН) МТП бақылаушы үлгілерімен салыстыру оларды синтездеу кезінде қолданылған шаблонға (сирек кездесетін металл ионына) қосымша қуыстардың бар екенін көрсетеді.

ЭГДМА (МТП-1) қатысында синтезделген МТП-дің меншікті электр өткізгіштігі мен рН мәні ДЭГДМА (МТП-2) қатысында синтезделген МТП-мен салыстырғанда (тығыз тігілудің салдарынан) анағұрлым жоғары екені анықталды.

Түйін сөздер: молекулалық таңбалы полимерлер, метакрил қышқылы, 4-винилпиридин, шаблон, сирек жер металдары. 


\title{
Резюме
}

\author{
T. K. Jumadilov, R. G. Kondaurov, A. M. Imangazy, Kh. Khimersen
}

\section{INFLUENCEOFCROSSLINKINGAGENTON ELECTROCHEMICAL AND CONFORMATIONAL BEHAVIOR OF MOLECULARLY IMPRINTED POLYMERS BASED ON METHACRYLIC ACID AND 4-VINYLPYRIDINE IN AN AQUEOUS MEDIUM}

Molecularly imprinted polymers (MIPs) based on methacrylic acid (MAA) and 4-vinylpyridine (4VP) of two types have been synthesized (the difference in types is based on the use of ethylene glycol dimethacrylate (EGDMA) and diethylene glycol dimethacrylate (DEGDMA) as a crosslinking agent). Salts of cerium, praseodymium, neodymium, samarium, and europium were used as templates for the synthesis. Control samples of Molecularly imprinted polymers were also synthesized (samples synthesized in exactly the same way, but without the templates).Electrochemical and conformational behavior of the synthesized structures in an aqueous medium was studied. Molecularly imprinted polymers are weakly exposed to swelling and ionization due to tight crosslinking, while it should be noted that a high degree of crosslinking leads to high mechanical strength of macromolecular structures.Comparison of the measured parameters (electrical conductivity, $\mathrm{pH}$ ) of molecularly imprinted polymers containing a template with control samples of MIP indicate the presence of cavities complementary to the template (rare-earth metal ion) used in their synthesis. In the presence of MIP synthesized in the presence of EGDMA (MIP-1) higher values of electrical conductivity and $\mathrm{pH}$ are observed as compared to MIP synthesized in the presence of DEGDMA (MIP-2) due to less tight crosslinking.

Keywords: molecularlyimprintedpolymers, methacrylicacid, 4-vinylpyridine, template, rare-earth metals.

\section{Information about authors:}

\begin{tabular}{|l|l|}
\hline $\begin{array}{l}\text { Jumadilov } \\
\text { Talkybek } \\
\text { Kozhataevich }\end{array}$ & $\begin{array}{l}\text { Doctor of Chemical Sciences, Professor, «A.B. Bekturov Institute of } \\
\text { Chemical Sciences» Joint Stock Company, Laboratory of Polymer } \\
\text { Synthesis and Physicochemistry, Almaty, the Republic of Kazakh- } \\
\text { stan; jumadilov@mail.ru; https://orcid.org/0000-0001-9505-3719 }\end{array}$ \\
\hline $\begin{array}{l}\text { Kondaurov } \\
\text { Ruslan } \\
\text { Gennadievich }\end{array}$ & $\begin{array}{l}\text { Ph.D, «A.B. Bekturov Institute of Chemical Sciences» Joint Stock } \\
\text { Almaty, the Republic of Kazakhstan; r-kondaurov@mail.ru; } \\
\text { https://orcid.org/0000-0001-5998-8453 }\end{array}$ \\
\hline $\begin{array}{l}\text { Imangazy } \\
\text { Maran }\end{array}$ & $\begin{array}{l}\text { Ph.D student, «A.B. Bekturov Institute of Chemical Sciences» Joint } \\
\text { Stock Company, Laboratory of Polymer Synthesis and }\end{array}$ \\
\hline $\begin{array}{l}\text { Khimersen } \\
\text { Khuangul }\end{array}$ & $\begin{array}{l}\text { Ph.D student, Abai Kazakh national pedagogical university, Almaty, } \\
\text { imangazy.aldan@mail.ru; https://orcid.org/0000-0001-7834-1022 }\end{array}$ \\
\hline https://orcid.org/0000-0002-5138-5997
\end{tabular}

